\title{
USEFULNESS OF BIOMARKERS AS INTERMEDIATE ENDPOINTS IN HEALTH RISKS POSED BY OCCUPATIONAL LEAD EXPOSURE
}

\author{
ANDREA BORGHINI ${ }^{1}$, EMILIO ANTONIO GIANICOLO ${ }^{1,2}$, and MARIA GRAZIA ANDREASSI ${ }^{1}$
}

${ }^{1}$ National Research Council, Lecce and Pisa, Italy

Institute of Clinical Physiology

${ }^{2}$ Johannes Gutenberg University, Mainz, Germany

Institute for Medical Biostatistics, Epidemiology and Informatics

\begin{abstract}
The article concerns potential harmful effects of exposure to lead. Although the occurrence of severe lead poisoning has receded in several countries, occupational exposure resulting in moderate and clinically symptomatic toxicity is still common. An earlier and precise characterization of an individual response is obligatory in order to assess the possible risks for human health. Biomarkers may fill important gaps in the path from exposure to a disease. Specifically speaking, emerging (DNA double strand breaks and telomeric DNA erosion) and validated (micronuclei induction and chromosomal aberrations) biomarkers of genotoxicity seem to provide evidence for the assessment of molecular and cellular damage. Moreover, identification of genetic variability with a key role in modulating genotoxic damage may help minimize risks for susceptible subjects. Further investigations are naturally needed to properly define their diagnostic and/or prognostic value as "early warning" signs of a long-term risk for a subsequent clinically overt disease.
\end{abstract}

Key words:

Biomarkers, Occupational exposure, Lead, Individual susceptibility, Genotoxic effects, Health risk

\section{INTRODUCTION}

Lead is a common environmental and occupational contaminant distributed worldwide. It is used in many industrial processes (e.g., household renovation, manufacturing and recycling of batteries, car repair, production of plastics, ceramics, paints and pigments) that may involve human exposure to this metal.

The battery industry is one of the leading sources of occupational lead exposure occurring in a variety of ways during processes of batteries manufacturing and recycling. Particularly, the battery industry uses an estimated $80 \%$ of annual primary lead (mined) and secondary lead (recycled) production [1]. Approximately $50 \%$ of global lead production is derived from lead batteries recycling [2].

Thus, occupational exposure to lead poses a serious threat to the health of industrial workers. Lead smelting and manufacture of lead alloy battery grids constitute major sources of lead oxides [3].

Contaminated air inside the battery industry factories poses a high risk of air-borne lead exposure. According to the World Health Organization (WHO), for each $1 \mathrm{mg} / \mathrm{m}^{3}$ increase in the concentration of lead in the air, the blood lead value increases by approximately $1.6 \mathrm{mcg} / \mathrm{dl}$. After absorption, lead enters blood stream and almost $95 \%$ of

Received: August 7, 2014. Accepted: June 12, 2015.

Corresponding author: A. Borghini, National Research Council, Institute of Clinical Physiology, Via Moruzzi 1, 56124 Pisa, Italy (e-mail: aborghini@ifc.cnr.it). 
it binds to erythrocytes [4]. Thus, exposure to lead is a great hazard for human health affecting a variety of fundamental biochemical processes [5].

The International Agency for Research on Cancer (IARC) classified it as a possible human carcinogen (Group 2B) [6] and its inorganic compounds as probable human carcinogens (Group 2A) [7]. Indeed, several epidemiological studies have linked exposure to lead to the increased incidence of cancers such as stomach, lung and bladder cancers [8]. Additionally, lead may cause numerous adverse health effects, including damage to the nervous, renal, cardiovascular, immune, and reproductive systems [9], as well as effects on bones and teeth $[10,11]$. However, epidemiologic evidence on many of the health effects of lead exposure has not been well-established, with uncertainties in latency, dose response relationships and population differences. Furthermore, epidemiological studies suffer from several key limitations, mainly due to the the small number of people, which makes it difficult to achieve sufficient statistical power in epidemiological studies, and the lack of information on potential confounders.

Finally, inter-individual genetic variability in metabolism capacity may also contribute to the variation in susceptibility to the effect of environmental stressors. Future insights into the health risks of exposure to lead require a more accurate characterization of an individual response. Biomarkers, defined as "any measurement reflecting an interaction between a biological system and an environmental agent" [12], may fill important gaps in the path from exposure to a disease by identifying high-risk groups of the overexposed or hypersusceptible subjects.

The purpose of this review is to discuss application of cellular and molecular biomarkers in the evaluation of health risks from occupational exposure to lead.

\section{FROM EXPOSURE TO HUMAN HEALTH EFFECTS}

\section{Biomarkers as a missing link}

Incorporation of molecular and cellular biomarkers into epidemiological studies has grown exponentially in recent years to better understand the relationship between environmental and/or occupational hazards and their effects on human health. The use of biomarkers is expected to identify important mechanistic insights into pathogenesis of disease processes and to reduce the time gap between exposure and recognition of disease-relevant effects. One of the goals of molecular epidemiology studies is to make use of biomarkers to develop more effective strategies to reduce the risk, such as: exposure monitoring, health surveillance and individual risk characterization $[13,14]$.

According to the International Program of Chemical Safety (IPCS), biomarkers are generally classified into 3 major categories i.e., exposure, effect and susceptibility [12]. Biomarkers of exposure are exogenous substances or their metabolites, or the products of an interaction between a xenobiotic agent and some target molecule or cell, which are measured in a given part within an organism. Specifically, the most frequently used biomarker of body lead burden is the blood lead concentration (blood lead level, BPb), reflecting a recent exposure level $[15,16]$. Additionally, measurement of $\delta$-aminolevulinic acid dehydratase (ALAD) activity and erythrocyte protoporphyrin (EP) concentration, biomarkers of $\mathrm{Pb}$ effect and/or exposure, provides an even more accurate evaluation of long-term cumulative exposure to lead [15].

Biomarkers of effect represent a measurable biochemical, physiological, behavioral or other alteration within an organism that, depending on the magnitude, can be recognized as associated with an established or possible health impairment. Therefore, biomarkers of effect indicate early signals of biologic effects preceding a disease and/or predict development and presence of a disease.

Finally, biomarkers of susceptibility (e.g., genetic polymorphisms) are indicators of an inherent or acquired ability of an organism to respond to the challenge of exposure to a specific xenobiotic agent. Indeed, genetic screening can be applied both as an indicator of susceptibility to occupational hazards or as a predictor of future health. 


\section{GENOTOXICITY AND OCCUPATIONAL EXPOSURE}

\section{Biomarkers of effect}

Although a number of studies in different biological systems have used different biomarkers to evaluate toxic effects of lead, there are still conflicting results regarding its genotoxicity [17]. Lead can interfere with cellular redox regulation and induce oxidative stress contributing to DNA damage and inhibition of major DNA repair systems and thus, resulting in genomic instability and accumulation of critical mutations (Figure 1) [18-23]. When combined with other DNA damaging agents (such as ultraviolet (UV) light, X-rays and certain chemicals), lead seems to result in an inhibition of DNA repair and an enhancement of genotoxicity by substituting calcium
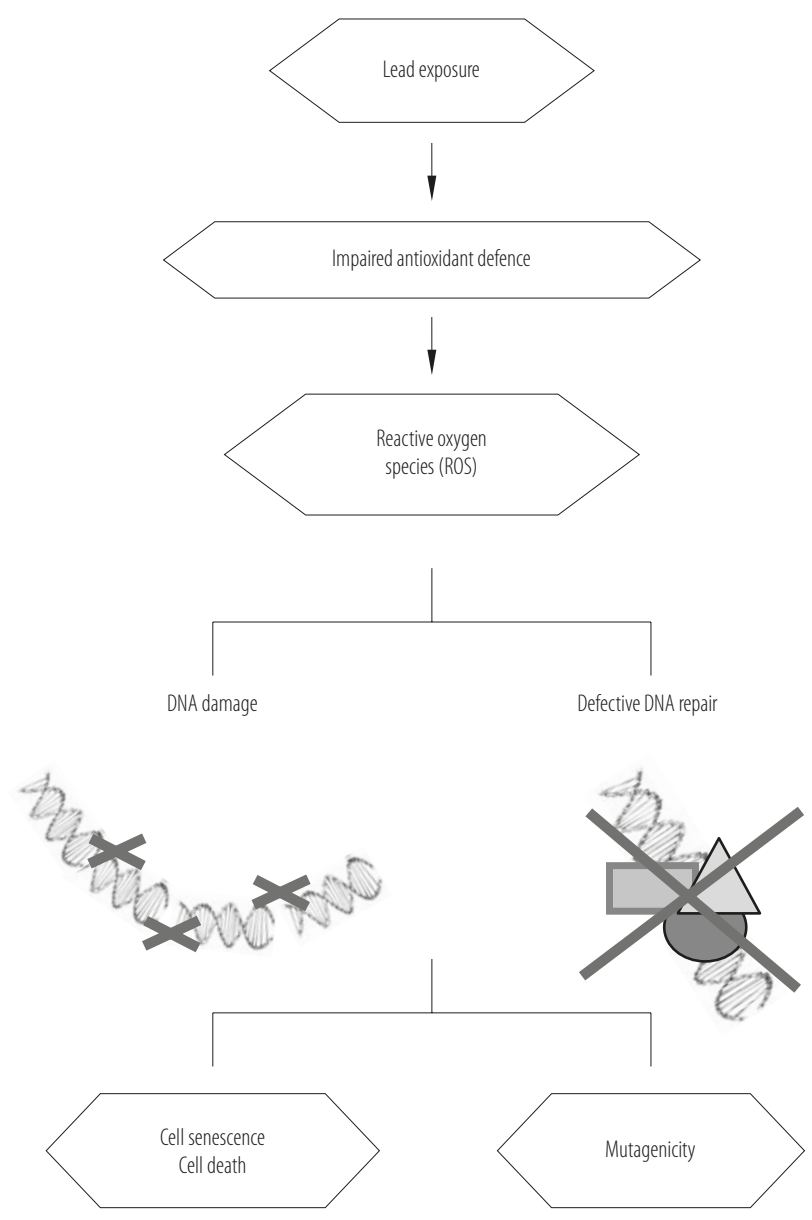

Fig. 1. Possible mechanism of lead-induced genotoxicity and/or zinc in enzymes involved in DNA replication, fidelity, and repair processes [24-26]. Below, there are reported the most frequently emerging (DNA double strand breaks and telomeric DNA erosion) and validated (micronucleus test and chromosomal aberrations) biomarkers of DNA lesions induced by toxic effects from occupational exposure to lead.

DNA double strand breaks (DSBs)

DNA double strand breaks (DSBs) constitute the most deleterious form of DNA damage, which, if not correctly repaired, can initiate genomic instability and mutations. The histone H2AX, known as the "histone guardian of the genome," is essential for initial recognition of DNA double strand breaks and a specific and efficient coordination of DNA repair mechanisms [27]. The histone $\mathrm{H} 2 \mathrm{AX}$ is rapidly phosphorylated $(\gamma-\mathrm{H} 2 \mathrm{AX})$ and there is a constant number or percentage of $\gamma$-H2AX formed per DSB. This highly amplified response can be visualized as a $\gamma$-H2AX focus in the chromatin that can be detected with the appropriate antibody [28-30]. Phosphorylation of the histone $\mathrm{H} 2 \mathrm{AX}$ ( $\gamma-\mathrm{H} 2 \mathrm{AX}$ form) is required for concentration and stabilization of DNA repair proteins, and plays a key role in both non-homologous end-joining (NHEJ) and homologous recombination (HR) repair pathways [31].

Double strand breaks may be induced by exogenous agents, such as ionizing radiation or drug [32], but they can also occur spontaneously during cellular processes at quite significant frequencies.

Molecular and cellular responses of human cells exposed to lead, have been recently investigated by focusing notably on DSB formation and repair. Gastaldo et al. have examined DNA damage response in human cells exposed to lead nitrate $\left(\mathrm{Pb}\left(\mathrm{NO}_{3}\right)_{2}\right)$ and its consequences upon the ataxia telangiectasia mutated (ATMdependent) stress signaling, cell cycle progression and cell death [33]. The authors have found that lead 
contamination generated late unrepairable DSBs that influenced the ATM-dependent stress signaling pathway by favoring propagation of errors. Particularly, as observed with anti-pH2AX immunofluorescence, exposure to lead resulted in a formation of late DSBs and inhibited the non-homologous end-joining repair process by preventing DNA-pyruvate kinase (PK) kinase activity, while the Meiotic Recombination 11 (MRE11)dependent repair pathway was exacerbated. Lead contamination triggered a successive synchronization of cells in the G2/M phase, in which the RAD51 recombinase (RAD51)-dependent homologous recombination was found to be activated [33].

Recently, an in vivo and in vitro study has investigated DSB formation in lymphocytes of workers exposed to lead. The authors have suggested that DSBs of the exposed group were significantly higher than those of the control group and increased in lymphocytes incubated at higher doses [34].

\section{Telomere length erosion}

Telomeres are specialized structures at the ends of chromosomes, and consist of tandem TTAGGG repeats bound to an array of specialized proteins that sequester telomeric DNA preventing it from being recognized as DNA damage [35]. In somatic cells, telomeres shorten at each cell division representing a mitotic clock of the senescence process. Telomeric DNA erosion is an important marker of cellular aging, and is associated with a greater risk of cancer and cardiovascular disease [35,36]. Telomeres are highly sensitive to oxidative stress due to less effective DNA repair than for intra-chromosomal sequences [37]. Specific targeting of telomeres could, thus, be indirectly attributed to lead induced oxidative stress. Specific alteration of this chromosomal region may have drastic consequences on the formation and long-term transmission of chromosomal rearrangements via their interplay with the natural aging of cells [37].
To date, little is known about changes in telomere length after occupational exposure to lead. A recent study has shown that lead exposure was associated with telomere shortening in leukocytes of Chinese battery manufacturing plant workers and directly proportional to the body lead burden, suggesting a possible link between lead exposure and the loss of telomere maintenance [38]. Although this study has only shown an association between lead exposure and telomere shortening, these results took on new significance in the light of the results subsequently presented by Pottier et al., which have strongly suggested a causal link between lead exposure at the cellular level and the loss of telomere maintenance [39]. The authors have indicated that the lead-induced generation of $\gamma-\mathrm{H} 2 \mathrm{Ax}$ foci at the end of chromosomes or near telomeres seems to be due to perturbation of telomere replication, in particular on the lagging DNA strand [39].

\section{Micronuclei induction}

Lead, as well as other heavy metals, can cause cytogenetic damage with the induction of micronuclei (MN) [17,4042], but the mechanisms of this phenomenon are still unknown. Micronuclei are small extranuclear bodies resulting from chromosome breaks or whole chromosomes lagging behind during anaphase. Micronuclei are easy to score both manually and using automated microscopy slide scanning and image analysis systems. They are scored in peripheral blood lymphocytes in the 1st interphase after cell division $[43,44]$. The cytokinesis-block procedure using cytochalasin B arrests division of cytoplasm or cytokinesis without inhibiting nuclear division and enables cells that may express chromosome damage as MN to be accumulated and recognized as binucleated (BN) cells. The frequency of $\mathrm{MN}$ in $\mathrm{BN}$ cells provides a consistent and reliable measure of chromosome damage $[45,46]$. Several studies have used MN assay to evaluate potential genotoxic effects induced by exposure to lead in individuals exposed in their workplaces (Table 1). 
The vast majority of researchers have demonstrated an increase in $\mathrm{MN}$ rate in exposed individuals compared with control groups, consequently highlighting the possible role of MN assay as a stable indicator of chronic lead exposure [21,26,40,42,47-58].

The only study that have not found any genotoxic effect using MN assay was that conducted by Hoffmann et al. [59]. They have investigated the effect of lead on the genetic material in a group of car repair and radiator reconditioning workers reporting an insignificant increase in $\mathrm{MN}$ in cultured peripheral blood lymphocytes of workers who were exposed to lead [59].

Evaluating a possible association between $\mathrm{MN}$ and biomarkers of $\mathrm{Pb}$ exposure (BPb, ALAD and $\mathrm{EP}$ ), Kasuba et al. have observed a negative correlation between ALAD and MN frequency, while EP positively correlated with MN [40]. Vaglenov et al. have also reported a significant correlation between $\mathrm{MN}$ formation and lead levels in workers from a storage battery plant [26]. When the authors examined 4 exposure levels, i.e., very low exposure $(<1.2 \mu \mathrm{M} / \mathrm{l})$, low exposure (1.2-1.91 $\mu \mathrm{M} / \mathrm{l})$, high exposure (1.92-2.88 $\mu \mathrm{M} / \mathrm{l})$, and very high exposure $(>2.88 \mu \mathrm{M} / 1)$, they have found significant differences in $\mathrm{MN}$ induction, concluding that occupational exposure to levels of lead higher than $1.2 \mu \mathrm{M} / 1$ may pose an increase in a genetic risk [26].

On the contrary, Pinto et al. have reported that occupational exposure time, but not the levels of lead, was significantly associated with cytogenetic damage [50].

\section{Chromosomal aberrations}

Chromosomal aberrations (CA) can result from either a variation in chromosome number or from structural changes. These events may occur spontaneously or can be induced by environmental agents such as chemicals, radiation and UV light. Disruption of DNA sequence or an excess or deficiency of the genes carried on the affected chromosomes results in a mutation.
Cytogenetic alterations detected by CA, but also by MN, reflect exposures that may have been experienced in the few months before a sample collection. Nevertheless, exposure in the previous 2-3years or even in a much longer period of time may equally affect these biomarkers [60].

There are contrasting results regarding the capacity of lead to cause chromosomal damage in exposed individuals as reviewed by Garcia-Leston et al. [17].

Some studies have reported increases in CA frequency in the subjects exposed to lead. On the other hand, other researchers have found no effects of lead exposure on CA frequency [17]. More recently, Coelho et al. have evaluated the extent of chromosomal alterations caused by environmental and occupational exposure in individuals previously tested for metal(loid) levels in different biological matrices, and the possible modulating role of genetic polymorphisms [41]. The results of the study have shown that lead contamination in the Panasqueira mine area induced genotoxic damage both in individuals working in the mine and living in the area. The observed effects were closely associated with the internal exposure dose and were more evident in susceptible genotypes [41].

\section{BIOMARKERS OF INDIVIDUAL SUSCEPTIBILITY Single nucleotide polymorphisms (SNPS) in genes involved in DNA repair and lead toxicokinetics}

The most common form of a genetic variation in the human population occurs as single nucleotide polymorphisms (SNPs). Identification of genetic polymorphisms, which have a key role in modulating genotoxic damage, may help minimize risks for susceptible subjects [61]. Genes involved in DNA repair mechanisms play a critical role in the maintenance of genome integrity, and variation in these genes may modulate the repair capacity. Single nucleotide polymorphisms in DNA repair genes involved in base excision repair (BER) pathway, NHEJ repair pathway and oxidative stress have been analyzed in different works as susceptibility biomarkers of occupational genotoxicity [41,57]. 


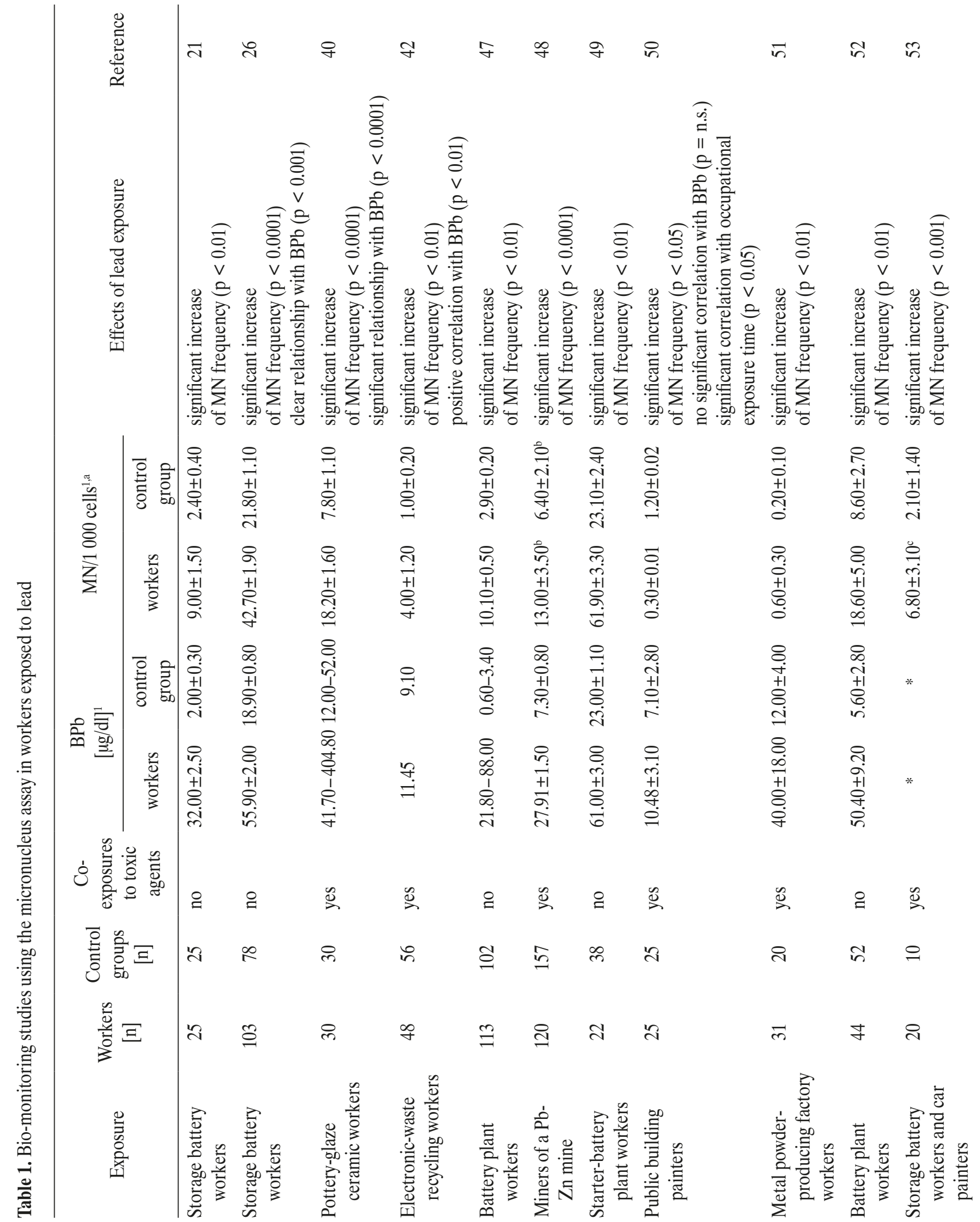




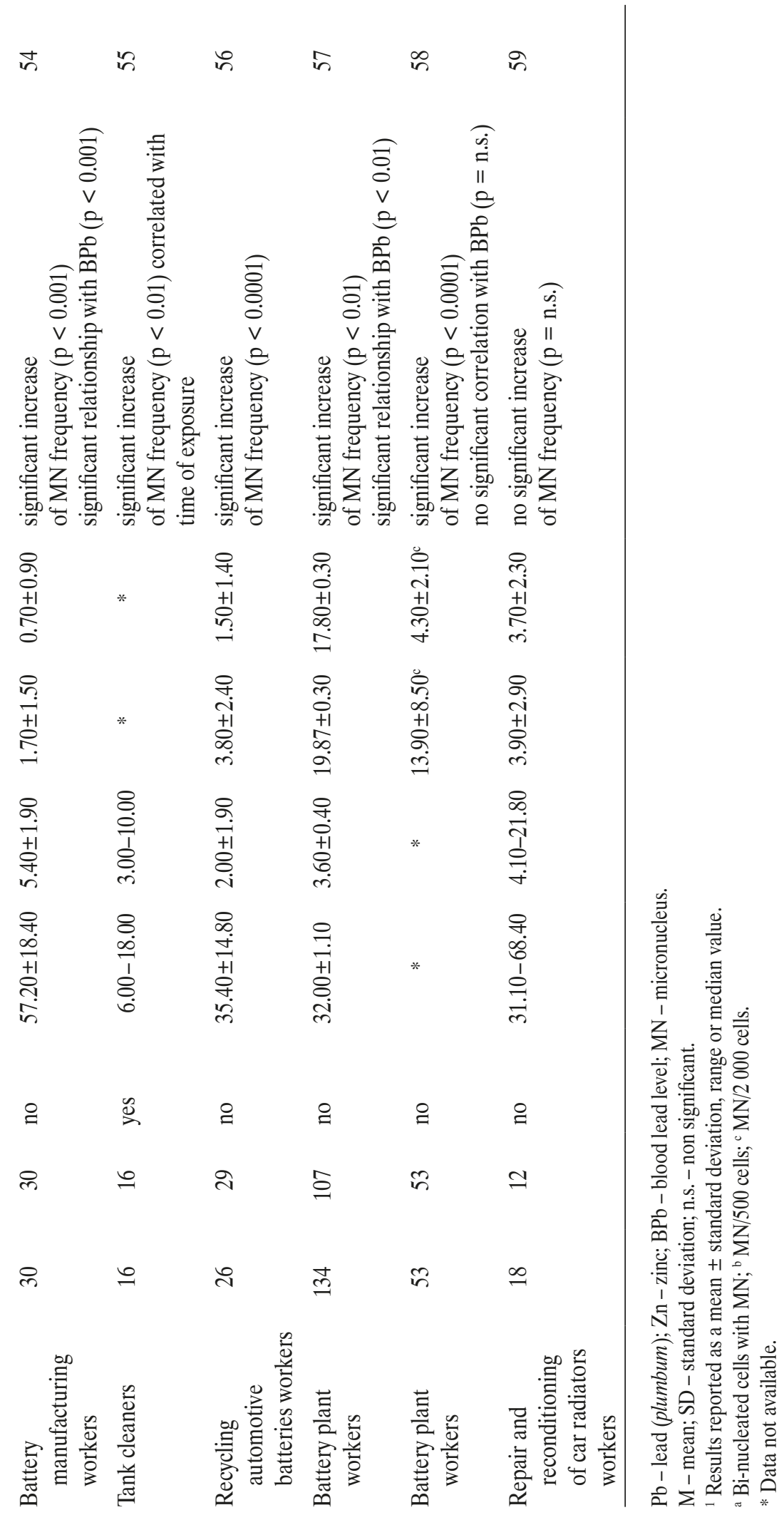


Recently, Garcia-Leston et al. [17] have evaluated individual susceptibility (18 SNPs in genes involved in DNA repair and 2 in lead toxicokinetics) to genotoxic effects from occupational lead exposure in 148 workers and 107 controls. Significant influence of Vitamin D receptor (VDR) gene polymorphism on BLL, and of polymorphisms in genes involved in BER and NHEJ, but not in HR, on genotoxic biomarker ( $\mathrm{MN}$ frequency) has been observed, suggesting a role of DNA repair and lead toxicokinetics polymorphisms as susceptibility biomarkers in occupational biomonitoring [57]. Vitamin D receptor and ALAD genetic variants are the only well-established susceptibility markers of lead toxicokinetics [62]. Vitamin D receptor plays a major role in maintaining calcium and phosphate homeostasis, and in regulating bone metabolism, and it is also involved in anti-proliferative, pro-apoptotic and immunosuppressive activities [63]. Because of their similar biochemical nature as divalent cations, calcium and lead often interact in the same biologic systems. For that reason, many cellular effects of lead are thought to be due to its effects on the normal function of calcium-dependent systems [64]. Schwartz et al. have first suggested that VDR polymorphism may play a role in susceptibility to lead bioaccumulation [65]. An association of VDR gene haplotypes and genotype combinations with susceptibility to occupational elevated blood lead levels has been subsequently found by Zhang et al. [66].

Moreover, ALAD is a zinc metalloenzyme the inhibition of which by lead is the most sensitive indicator of lead exposure, and the decreased activity of which has been implicated in the pathogenesis of lead toxicity. This heme biosynthetic enzyme is encoded by a gene located at chromosome 9q34. Several studies [67-70] have demonstrated an association of ALAD G177C polymorphism (rs1800435) with accumulation of lead in the blood, emphasizing its possible role in the evaluation and better understanding of consequences of exposure. On the contrary, Leroyer et al. have shown that ALAD polymorphism exerts no marked impact on the lead body burden [71].

\section{CONCLUSIONS}

Occupational exposure to lead is clearly a major public health hazard with global dimension. Public health measures should continue to be aimed at reduction and prevention of exposure to lead by minimizing lead-containing emissions that result in human exposure [72]. Although the occurrence of severe lead poisoning has largely receded in many countries, occupational exposure to lead resulting in moderate and clinically symptomatic toxicity is still common.

Future insights into human health risk assessment require an earlier and more accurate characterization of an individual response. Contextually, biomarkers are key elements and are the "early warning" signs capable of identifying a long-term risk of a subsequent clinically overt disease that can help define individual risks and potential intervention strategies. Genotoxicity biomarkers should prove very important for evaluating the extent of damage that may be modulated by individual genetic susceptibility.

Additionally, recent progress in "-omic" technologies offers an unprecedented opportunity to characterize new biomarkers of exposure and inter-individual variability in response to exposure, as well as to better define the health risk from occupational exposure [73]. Identification of such biomarkers may be useful for identifying a subset of individuals who are more vulnerable to lead exposure, anticipating delayed health outcomes and providing a greater potential for preventive measures.

\section{REFERENCES}

1. International Lead and Zinc Study Group [Internet]. Lisbon: The Group; 2015 [cited 2011 Jan 12]. End uses of lead. Available from: http://www.ilzsg.org/static/enduses.aspx?from =2.

2. Thornton I, Rautiu R, Brush S. Lead: The facts. London: IC Consultants Ltd.; 2001. p. 65-71.

3. Al-Hakkak ZS, Hamamy HA, Murad AMB, Hussain AF. Chromosome aberrations in workers at a storage battery 
plant in Iraq. Mutat Res. 1986;171:53-60, http://dx.doi.org/ 10.1016/0165-1218(86)90008-X.

4. Cavalleri A, Minoia C, Pozzoli L. Determination of plasma lead levels in normal subjects and in lead exposed workers. $\mathrm{Br}$ J Ind Med. 1978;35:21-6, http://dx.doi.org/10.1136/oem.35.1.21.

5. Pokrsa MA, Kneeland MR. Lead poisoning: Using transdisciplinary approaches to solve an ancient problem. Ecohealth. 2008;5:379-85, http://dx.doi.org/10.1007/s10393-0080177-x.

6. International Agency for Research on Cancer. IARC monographs on the evaluation of carcinogenic risks to humans. Vol. 23: Some metals and metallic compounds. Lyon: The Agency; 1980.

7. International Agency for Research on Cancer. IARC monographs on the evaluation of carcinogenic risks to humans. Vol. 87: Inorganic and organic lead compounds. Lyon: The Agency; 2006.

8. Fu H, Boffetta P. Cancer and occupational exposure to inorganic lead compounds: A meta-analysis of published data. Occup Environ Med. 1995;52:73-81, http://dx.doi. org/10.1136/oem.52.2.73.

9. Agency for Toxic Substances and Disease Registry. Toxicological profile for lead. Atlanta (GA): The Agency; 2007.

10. Mansouri MT, Cauli O. Motor alterations induced by chronic lead exposure. Environ Toxicol Pharmacol. 2009;27:307-13, http://dx.doi.org/10.1016/j.etap.2009.01.003.

11. García-Lestón J, Roma-Torres J, Mayan O, Schroecksnadel S, Fuchs D, Moreira AO, et al. Assessment of immunotoxicity parameters in individuals occupationally exposed to lead. J Toxicol Environ Health. 2012;75:807-18, http:// dx.doi.org/10.1080/15287394.2012.690327.

12. World Health Organization. Biomarkers and risk assessment: Concepts and principles. Environmental health criteria 155. Geneva: The Organization; 1993.

13. Neta R. The promise of molecular epidemiology in defining the association between radiation and cancer. Health Phys. 2000;79:77-84, http://dx.doi.org/10.1097/00004032200007000-00013.
14. Vineis P, Perera F. Molecular epidemiology and biomarkers in etiologic cancer research: The new in light of the old. Cancer Epidemiol Biomarkers Prev. 2007;16:1954-65, http:/ dx.doi.org/10.1158/1055-9965.EPI-07-0457.

15. Alessio L, Castoldi MR, Odone P, Franchini I. Behaviour of indicators of exposure and effect after cessation of occupational exposure to lead. Br J Ind Med. 1981;38:262-7, http:/ dx.doi.org/10.1136/oem.38.3.262.

16. Telisman S, Kersanc A, Prpic-Majic D. The relevance of arguments for excluding ALAD from the recommended biological limit values in occupational exposure to inorganic lead (WHO 1980). Int Arch Occup Environ Health. 1982;50:397-412, http://dx.doi.org/10.1007/ BF00377836.

17. Garcia-Leston J, Mendez J, Pasaro E, Laffon B. Genotoxic effects of lead: An updated review. Environ Int. 2010;36: 623-36, http://dx.doi.org/10.1016/j.envint.2010.04.011.

18. Méndez-Gómez J, Garcia-Vargas GG, Lopez-Carrillo L, Calderón-Aranda ES, Gómez A, Vera E, et al. Genotoxic effects of environmental exposure to arsenic and lead on children in region Lagunera, Mexico. Ann N Y Acad Sci. 2008;1140:358-67, http://dx.doi.org/10.1196/annals.14 54.027 .

19. Hartwig A. Role of DNA repair inhibition in lead- and cadmium-induced genotoxicity: A review. Environ Health Perspect. 1994;102 Suppl 3:45-50.

20. Silbergeld EK. Facilitative mechanisms of lead as a carcinogen. Mutat Res. 2003;533:121-33, http://dx.doi.org/10.1016/ j.mrfmmm.2003.07.010.

21. Chen Z, Lou J, Chen S, Zheng W, Wu W, Jin L, et al. Evaluating the genotoxic effects of workers exposed to lead using micronucleus assay, comet assay and TCR gene mutation test. Toxicology. 2006;223:219-26, http://dx.doi.org/10. 1016/j.tox.2006.03.016.

22. Woźniak K, Blasiak J. In vitro genotoxicity of lead acetate: induction of single and double DNA strand breaks and DNA-protein cross-links. Mutat Res. 2003;535:127-39, http://dx.doi.org/10.1016/S1383-5718(02)00295-4. 
23. Johnson FM. The genetic effects of environmental lead. Mutat Res. 1998;410:123-40, http://dx.doi.org/10.1016/S13835742(97)00032-X.

24. Hartwig A, Schlepergrell R, Beyersmann D. Indirect mechanism of lead induced genotoxicity in cultured mammalian cells. Mutat Res. 1990;241:75-82, http://dx.doi. org/10.1016/0165-1218(90)90110-N.

25. Johansson L, Pelliccari CE. Lead induced changes in the stabilization of the mouse sperm chromatin. Toxicology. 1988;51:11-24, http://dx.doi.org/10.1016/0300-483 X(88)90076-5.

26. Vaglenov A, Creus A, Laltchev S, Petkova V, Pavlova S, Mar$\cos \mathrm{R}$, et al. Occupational exposure to lead and induction of genetic damage. Environ Health Perspect. 2001;109:295-8.

27. Fernandez-Capetillo O, Lee A, Nussenzweig M, Nussenzweig A. H2AX: The histone guardian of the genome. DNA Repair (Amst). 2004;3:959-67, http://dx.doi. org/10.1016/j.dnarep.2004.03.024.

28. Pilch DR, Sedelnikova OA, Redon C, Celeste A, Nussenzweig A, Bonner WM. Characteristics of $\gamma$-H2AX foci at DNA double-strand breaks sites. Biochem Cell Biol. 2003;81:123-9, http://dx.doi.org/10.1139/003-042.

29. Redon C, Pilch D, Rogakou E, Sedelnikova O, Newrock K, Bonner W. Histone H2A variants H2AX and H2AZ. Curr Opin Genet Dev. 2002;12:162-9, http://dx.doi.org/10.1016/ S0959-437X(02)00282-4.

30. Sedelnikova OA, Pilch DR, Redon C, Bonner WM. Histone H2AX in DNA damage and repair. Cancer Biol Ther. 2003;2:233-5.

31. Shrivastav M, de Haro LP, Nickoloff JA. Regulation of DNA double-strand break repair pathway choice. Cell Res. 2008;18:134-47, http://dx.doi.org/10.1038/cr.2007.111.

32. Pfeiffer P, Goedecke W, Obe G. Mechanisms of DNA double-strand break repair and their potential to induce chromosomal aberrations. Mutagenesis. 2000;15:289-302, http:// dx.doi.org/10.1093/mutage/15.4.289.

33. Gastaldo J, Viau M, Bencokova Z, Joubert A, Charvet AM, Balosso J, et al. Lead contamination results in late and slowly repairable DNA doublestrand breaks and impacts upon the ATM dependent signaling pathways. Toxicol Lett. 2007;173:201-14, http://dx.doi.org/10.1016/j.toxlet. 2007.08.003.

34. Luo MJ, Hu XJ, Li C, Yang J, Wang J. The investigation of DNA double-strand breaks of lymphpcytes in workers exposed to lead and DNA double-strand breaks of human lymphocytes induced by lead in vitro. Zhonghua Lao Dong Wei Sheng Zhi Ye Bing Za Zhi. 2012;30:216-9.

35. Fyhrquist F, Saijonmaa O, Strandberg T. The roles of senescence and telomere shortening in cardiovascular disease. Nat Rev Cardiol. 2013;10:274-83, http://dx.doi.org/10.1038/ nrcardio.2013.30.

36. Kong CM, Lee XW, Wang X. Telomere shortening in human diseases. FEBS J. 2013;280:3180-93, http://dx.doi. org/10.1111/febs.12326.

37. Ayouaz A, Raynaud C, Heride C, Revaud D, Sabatier L. Telomeres: Hallmarks of radiosensitivity. Biochimie. 2008;90: 60-72, http://dx.doi.org/10.1016/j.biochi.2007.09.011.

38. Wu Y, Liu Y, Ni N, Bao B, Zhang C, Lu L. High lead exposure is associated with telomere length shortening in Chinese battery manufacturing plant workers. Occup Environ Med. 2012;69:557-63, http://dx.doi.org/10.1136/ oemed-2011-100478.

39. Pottier G, Viau M, Ricoul M, Shim G, Bellamy M, Cuceu $\mathrm{C}$, et al. Lead exposure induces telomere instability in human cells. PLoS One. 2013;8:e67501, http://dx.doi. org/10.1371/journal.pone.0067501.

40. Kašuba V, Rozgaj R, Milić M, Zelježić D, Kopjar N, Pizent A, et al. Evaluation of genotoxic effects of lead in pottery-glaze workers using micronucleus assay, alkaline comet assay and DNA diffusion assay. Int Arch Occup Environ Health. 2012;85:807-18, http://dx.doi.org/10.1007/s00420011-0726-4.

41. Coelho P, García-Lestón J, Costa S, Costa C, Silva S, Dall'Armi V, et al. Genotoxic effect of exposure to metal(loid)s. A molecular epidemiology survey of populations living and working in Panasqueira mine area, Portugal. 
Environ Int. 2013;60:163-70, http://dx.doi.org/10.1016/j.envint.2013.08.014.

42. Wang Q, He AM, Gao B, Chen L, Yu QZ, Guo H, et al. Increased levels of lead in the blood and frequencies of lymphocytic micronucleated binucleated cells among workers from an electronic-waste recycling site. J Environ Sci Health A Tox Hazard Subst Environ Eng. 2011;46:669-76, http:// dx.doi.org/10.1080/10934529.2011.563176.

43. Willems P, August L, Slabbert J, Romm H, Oestreicher U, Thierens H, et al. Automated micronucleus (MN) scoring for population triage in case of large scale radiation events. Int J Radiat Biol. 2010;86:2-11, http://dx.doi. org/10.3109/09553000903264481.

44. Rossnerova A, Spatova M, Schunck C, Sram RJ. Automated scoring of lymphocyte micronuclei by the MetaSystems Metafer image cytometry system and its application in studies of human mutagen sensitivity and biodosimetry of genotoxin exposure. Mutagenesis. 2011;26:169-75, http://dx.doi. org/10.1093/mutage/geq057.

45. Fenech M, Morley AA. Measurement of micronuclei in lymphocytes. Mutat Res. 1985;147:29-36, http://dx.doi. org/10.1016/0165-1161(85)90015-9.

46. Norppa H, Hayashi M, Maki-Paakkanen J, Sorsa M. The micronucleus assay in lymphocytes. Prog Clin Biol Res. 1990;340B:207-16.

47. Shaik AP, Jamil K. Individual susceptibility and genotoxicity in workers exposed to hazardous materials like lead. J Hazard Mater. 2009;168:918-24, http://dx.doi.org/10.1016/ j.jhazmat.2009.02.129.

48. Bilban M. Influence of the work environment in a $\mathrm{Pb}-\mathrm{Zn}$ mine on the incidence of cytogenetic damage in miners. Am J Ind Med. 1998;34:455-63, http://dx.doi.org/10.1002/(SICI)10970274(199811)34:5<455::AID-AJIM6>3.0.CO;2-P.

49. Vaglenov A, Carbonell E, Marcos R. Biomonitoring of workers exposed to lead. Genotoxic effects, its modulation by polyvitamin treatment and evaluation of the induced radioresistance. Mutat Res. 1998;418:79-92, http://dx.doi. org/10.1016/S1383-5718(98)00111-9.
50. Pinto D, Ceballos JM, Garcia G, Guzmán P, del Razo LM, Vera E, et al. Increased cytogenetic damage in outdoor painters. Mutat Res. 2000;467:105-11, http://dx.doi.org/10.1016/ S1383-5718(00)00024-3.

51. Hamurcu Z, Donmez H, Saraymen R, Demirtas H. Micronucleus frequencies in workers exposed to lead, zinc, and cadmium. Biol Trace Elem Res. 2001;83:97-102, http:// dx.doi.org/10.1385/BTER:83:2:097.

52. Palus J, Rydzynski K, Dziubaltowska E, Wyszynska K, Natarajan AT, Nilsson R. Genotoxic effects of occupational exposure to lead and cadmium. Mutat Res. 2003;540:19-28, http://dx.doi.org/10.1016/S1383-5718(03)00167-0.

53. Martino-Roth MG, Viegas J, Roth DM. Occupational genotoxicity risk evaluation through the comet assay and the micronucleus test. Genet Mol Res. 2003;2:410-7.

54. Singh Z, Chadha P, Sharma S. Evaluation of oxidative stress and genotoxicity in battery manufacturing workers occupationally exposed to lead. Toxicol Int. 2013;20:95-100, http:// dx.doi.org/10.4103/0971-6580.111550.

55. Hogstedt B, Gullberg B, Mark-Vendel E, Mitelman F, Skerfving S. Micronuclei and chromosome aberrations in bone marrow cells and lymphocytes of humans exposed mainly to petroleum vapors. Hereditas. 1981;94:179-87, http://dx.doi. org/10.1111/j.1601-5223.1981.tb01751.x.

56. Minozzo R, Deimling LI, Gigante LP, Santos-Mello R. Micronuclei in peripheral blood lymphocytes of workers exposed to lead. Mutat Res. 2004;565:53-60, http://dx.doi. org/10.1016/j.mrgentox.2004.09.003.

57. García-Leston J, Roma-Torres J, Vilares M, Pinto R, Prista J, Teixeira JP, et al. Genotoxic effects of occupational exposure to lead and influence of polymorphisms in genes involved in lead toxicokinetics and in DNA repair. Environ Int. 2012;43:29-36, http://dx.doi.org/10.1016/j.envint.2012.03.001.

58. Minozzo R, Deimling RI, Santos-Mello R. Cytokinesisblocked micronucleus cytome and comet assays in peripheral blood lymphocytes of workers exposed to lead considering folate and vitamin $B_{12}$ status. Mutat Res. 2010;697:24-32, http://dx.doi.org/10.1016/j.mrgentox.2010.01.009. 
59. Hoffmann M, Hagberg S, Karlsson A, Nilsson R, Ranstam J, Högstedt B. Inorganic lead exposure does not effect lymphocyte micronuclei in car radiator repair workers. Hereditas. 1984;101:223-6, http://dx.doi.org/10.1111/ j.1601-5223.1984.tb00919.x.

60. Liu Q, Cao J, Liu Y, Lü YM, Qin B, Jiang B, et al. Followup study by chromosome aberration analysis and micronucleus assays in victims accidentally exposed to 60Co radiation. Health Phys. 2010;98:885-8, http://dx.doi.org/10.1097/ HP.0b013e3181c4b9c1.

61. Costa S, Coelho P, Costa C, Silva S, Mayan O, Santos LS, et al. Genotoxic damage in pathology anatomy laboratory workers exposed to formaldehyde. Toxicology. 2008;252:40-8, http:// dx.doi.org/10.1016/j.tox.2008.07.056.

62. Gundacker C, Gencik M, Hengstschläger M. The relevance of the individual genetic background for the toxicokinetics of 2 significant neurodevelopmental toxicants: Mercury and lead. Mutat Res. 2010;705:130-40, http://dx.doi. org/10.1016/j.mrrev.2010.06.003.

63. Hendy GN, Hruska KA, Mathew S, Goltzman D. New insights into mineral and skeletal regulation by active forms of vitamin D. Kidney Int. 2006;69:218-23, http://dx.doi. org/10.1038/sj.ki.5000091.

64. Pounds JG. Effect of lead intoxication on calcium homeostasis and calcium-mediated cell function: A review. Neurotoxicology. 1984;5:295-331.

65. Schwartz BS, Stewart WF, Kelsey K, Simon D, Park S, Links JM, et al. Associations of tibial lead levels with Bsml polymorphisms in the vitamin D receptor in former organolead manufacturing workers. Environ Health Perspect. 2000;108:199-203, http://dx.doi.org/10.1289/ehp. 00108199.

66. Zhang Y, Wu YX, Liu YM, Yang ZQ, Zhang C, Wang ZY. Association of vitamin D receptor gene haplotypes and genotype combinations with susceptibility to occupational elevated blood lead. Zhonghua Lao Dong Wei Sheng Zhi Ye Bing Za Zhi. 2013;31:121-4.

67. Tian L, Zheng G, Sommar JN, Liang Y, Lundh T, Broberg $\mathrm{K}$, et al. Lead concentration in plasma as a biomarker of exposure and risk, and modification of toxicity by $\delta$-aminolevulinic acid dehydratase gene polymorphism. Toxicol Lett. 2013;221:102-9, http://dx.doi.org/10.1016/j.toxlet.2013.06.214.

68. Zheng G, Tian L, Liang Y, Broberg K, Lei L, Guo W, et al. $\delta$-Aminolevulinic acid dehydratase genotype predicts toxic effects of lead on workers' peripheral nervous system. Neurotoxicology. 2011;32:374-82, http://dx.doi. org/10.1016/j.neuro.2011.03.006.

69. Gao A, Lu XT, Li QY, Tian L. Effect of the delta-aminolevulinic acid dehydratase gene polymorphism on renal and neurobehavioral function in workers exposed to lead in China. Sci Total Environ. 2010;408:4052-5, http://dx.doi. org/10.1016/j.scitotenv.2010.04.024.

70. Shaik AP, Jamil K. A study on the ALAD gene polymorphisms associated with lead exposure. Toxicol Ind Health. 2008;24:501-6, http://dx.doi.org/10.1177/074823370 8095770.

71. Leroyer A, Leleu B, Dehon B, Frimat P, Broly F, Nisse C. Influence of delta-aminolevulinic acid dehydratase gene polymorphism on selected lead exposure biomarkers in a cohort of ex-smelter workers. J Toxicol Environ Health A. 2013;76: 895-906, http://dx.doi.org/10.1080/15287394.2013.824843.

72. Tong S, von Schirnding YE, Prapamontol T. Environmental lead exposure: A public health problem of global dimensions. Bull World Health Organ. 2000;78:1068-77.

73. Vlaanderen J, Moore LE. Application of OMICS technologies in occupational and environmental health research; current status and projections. Occup Environ Med. 2010;67:136-43, http://dx.doi.org/10.1136/oem.2008. 042788 .

This work is available in Open Access model and licensed under a Creative Commons Attribution-NonCommercial 3.0 Poland License - http://creativecommons.org/ licenses/by-nc/3.0/pl/deed.en. 